\title{
DEVELOPMENT OF INFORMATION COMPETENCIES AND COMPUTER LITERACY OF SECONDARY SCHOOL GRADUATES
}

\author{
Libuša RÉVÉSZOVÁ
}

\begin{abstract}
The article summarizes results of the research of information competencies and computer literacy of secondary school graduates who entered the first grade at the Economics Faculty Technical University in Košice. We compared the results of questionnaires from 2003-2005 and 2009-2011.
\end{abstract}

Key words: education, information competences, computer literacy

\section{VÝVOJ V OBLASTI INFORMAČNEJ A POČÍTAČOVEJ GRAMOTNOSTI ABSOLVENTOV STREDNÝCH ŠKÔL}

Resumé: Článok sumarizuje výsledky výskumu v oblasti počítačovej a informačnej gramotnosti na vzorke absolventov stredných škôl, ktorí nastúpili do prvého ročníka Ekonomickej fakulty Technickej univerzity v Košiciach. Mapuje situáciu a zmeny, ktoré nastali porovnaním výsledkov dotazníkového prieskumu v rokoch 2003, 2004, 2005 a 2009, 2010, 2011.

Kl'účové slova: vzdelávanie, informačná gramotnost', počítačová gramotnost'.

\section{1 Úvod}

„Vaša schopnost' zbierat', spracovávat' a využivat' informácie rozhoduje o tom, či budete patrit' $k$ vit’azom alebo porazeným" napísal Bill Gates už v roku 1999 ([7] str. 19). Odvtedy význam jeho slov neustále rastie. Okrem iného to potvrdzujú aj nasledujúce fakty: pred viac ako 10 rokmi sa práca $\mathrm{s}$ informáciami podiel'ala na tvorbe HDP vo vyspelých krajinách 50 až 60 percentami. [2] Očakáva sa, že v roku 2020 bude podiel manuálnych pracovníkov tvorit' len 10 až 12 percent $\mathrm{z}$ celkového počtu. [4]

Pod vplyvom prieniku informačných a komunikačných technológií (IKT) do všetkých oblastí života a tiež zásluhou nastupujúcich znalostných technológií sa vytvára sa celkom nové prostredie znalostnej spoločnosti.

Často sa stretávame $\mathrm{s}$ názorom, že tým prvoradým v rozvoji, implementácii a efektívnej aplikácii IKT sú vyspelé technické zariadenia, počítače - hardvér, softvér. Tieto sú samozrejme neodmyslitel'nou súčast'ou, avšak kl'účovým prvkom sú l'udia - používatelia, ako to uvádza napr.[6] Od kompetentných používatel'ov závisí, čo budú od IKT, informačných systémov (IS) a informatiky ako takej vyžadovat', aké budú ich požiadavky na informácie, ich kvantitu a kvalitu. $\mathrm{Na}$ použivatel'och, na ich motivácii, záujme a kvalifikácii vždy závisí, aký bude výsledný efekt a návratnost' často vel'mi vysokých investícií do projektov informatizácie a zavádzania výpočtovej techniky kdekol’vek.
Je zrejmé, že podpora a rozvoj informačnej a počítačovej gramotnosti používatel'ov na všetkých úrovniach by mali byt' v popredí záujmu. Rovnako je zrejmé, že sa týmto spoločenským požiadavkám musí prispôsobovat' vzdelávací systém, a to na všetkých stupňoch. Požadovaný stav a realita sa však nemusia zhodovat'.

\section{Vymedzenie informačnej a počítačovej gramotnosti}

Pojmy informačná a počítačová gramotnost' sa často používajú nepresne a tiež sa mnohokrát zamieňajú. $V$ našom ponímaní chápeme uvedené pojmy nasledovne.

Pojem informačná gramotnost' sa používa od sedemdesiatych rokov 20. storočia. Podl'a prezidenta „Information Industry Association“ Paula Zurkowského sú informačne gramotní ludia takí, ktorí sú pripravení používat' informačné zdroje pri práci a ktorí sa naučili využívat' širokú škálu techník a informačných nástrojov rovnako ako primárne zdroje pri riešení problému (uvedené v [10]). Ďalšie zdroje uvádzajú nasledovné vymedzenia:

- Informačná gramotnost' je schopnost' efektívne vyhl'adávat' a hodnotit' informácie vzt'ahujúce sa k určitej potrebe. [1]

- Informačná gramotnost' je schopnost' využívat' moderné informačné technológie a prostriedky v bežnom živote. [8]

Ak vezmeme do úvahy d'alšie definície, do informačnej gramotnosti treba zahrnút' aj 
schopnost' uvedomit' si a formulovat' svoje informačné potreby, orientovat sa $\mathrm{v}$ informačných zdrojoch, schopnost' poznat' kedy sú informácie potrebné, vediet' ich vyhl'adat' prostredníctvom IKT, vyhodnotit' a efektívne využit' pri riešení konkrétnej životnej situácie či odborného problému.

$\mathrm{Z}$ nášho pohladu najviac vyhovuje vymedzenie podl'a [3], kde sa informačne gramotný človek chápe ako ten, ktorý má osvojené nasledujúce spôsobilosti a dokáže:

- identifikovat' informačné potreby,

- dokáže zvolit' vhodnú stratégiu pre získanie informácií,

- využívat' zodpovedajúce zdroje a IS,

- v informačných zdrojoch vyhl'adat' požadované informácie,

- získané informácie kriticky zhodnotit',

- informácie vhodne spracovat' a využit',

- informácie sprostredkovat' iným l'ud'om v rôznych podobách a prostredníctvom rôznych technológií,

- posúdit' morálne a právne aspekty využívania informácií.

Počítačová gramotnost' je predpokladom pre dosiahnutie dobrej úrovne informačnej gramotnosti a podl'a[3] predstavuje schopnosti a spôsobilosti ovládat' a využívat' počítač a jeho periférie, rovnako ako schopnost' pracovat' s bežným softvérovým vybavením, využívat' počítačové siete, predovšetkým Internet.

V [12] sa počítačová gramotnost' vymedzuje ako súbor kompetencií, ktoré umožňujú človeku využívat' nové technológie $\mathrm{v}$ jeho profesionálnom i osobnom živote $v$ takej miere, že sa necíti (počítačovo) hendikepovaný, nie je za digitálnou hrádzou a jeho osobný či profesionálny rozvoj prostredníctvom využitia počítača je len otázkou jeho vol'by.

Informačná gramotnost' je teda širší pojem. U informačne gramotného človeka sa počítačová gramotnost' predpokladá, naopak to však platit' nemusí. [3]

\section{Vzdelávanie pre znalostnú spoločnost'}

$\mathrm{Na}$ Ekonomickej fakulte Technickej univerzity $v$ Košiciach (EkF TUKE) je naše pôsobenie zamerané na vzdelávanie manažérov, t.j. budúcich pokročilých používatel'ov IKT v oblastiach moderného riadenia firiem a širokého využívania e-aplikácii v oblasti obchodu, financií, bankovníctva a investovania. $\mathrm{Na}$ základe požiadaviek praxe a nastupujúcej znalostnej spoločnosti považujeme za nevyhnutné modernizovat' obsah a formy vzdelávania transferom skúseností z praxe (napr. z riešenia vedeckovýskumných projektov), posúvat' výučbu na kvalitatívne vyššiu úroveň.

Je nesporné, že riešenie problémov podporuje učenie a zapamätanie poznatkov. Preto vo výučbe predmetov Informatika I a Informatika II (v prvom ročníku bakalárskeho stupňa) preferujeme projektovú metódu - študenti aktívne participujú na výučbe prostredníctvom vypracovania semestrálnych projektov v prvom semestri návrh a príprava webovej stránky, $\mathrm{v}$ druhom semestri - projekt zadania použivatel'ských požiadaviek na jednoduchý informačný systém.

Efektívnost' učenia je výrazne ovplyvňovaná zvolenými stratégiami. Uvedomujeme si, že vel'mi záleží na spôsoboch, akými sú študentom problémy predkladané, a na tom či náročnost' riešenia daných problémov zodpovedá stupňu rozvoja jedincov. Dôležité je, či študenti majú na riešenie problému dostatok vedomostí a zručností. Preto je potrebné overit' do akej miery študenti rozumejú podstate problému, aby jeho následné riešenie zodpovedalo ich možnostiam a pripravenosti. [9]

Ked'že predmety Informatika I a II sú povinnými predmetmi v prvom ročníku, dôležitým vstupom je báza vedomostí, schopností a zručností, s ktorou prichádzajú študenti po absolvovaní stredných škôl. To predstavuje základňu na ktorej môžeme stavat' my aj študenti. Úroveň informačnej a počítačovej gramotnosti ovplyvňuje d’alšiu výučbu (nielen informatiky), správne nastavenie a modifikáciu obsahu, rozsahu, metód a foriem výučby.

\section{Vývoj v oblasti počítačovej gramotnosti absolventov stredných škôl}

Otázkou teda je: S akou úrovňou informačnej a počítačovej gramotnosti prichádzajú absolventi stredných škôl?

Touto otázkou sa zaoberáme od akademického roku 2003/2004. Pomocou dotazníka, administrovaného na úvodných cvičeniach predmetu Informatika I, v prvom semestri skúmame rozsah a obsah (základného, povinného) vzdelania voblasti informatiky, s ktorým prichádzajú študenti po absolvovaní strednej školy (SŠ).

Pri zostavovaní dotazníka, vytváraní jednotlivých položiek sme vychádzali z platnej legislatívy, zo základných pedagogických dokumentov [11], [13] a štandardov [5].

Pre možnost' porovnania vývoja v oblasti informačnej a počítačovej gramotnosti uvádzame 
v tabul'kách a grafoch výsledky vyhodnotenia dotazníkových položiek z rokov 2003, 2004, 2005 a následne z rokov 2009, 2010 a 2011.

Prezentujeme výsledky odpovedí celkového počtu (CP) 976 respondentov. Zastúpenie absolventov jednotlivých typov stredných škôl vo vzorke bolo nasledovné:

- gymnázium (G): 852 - $87 \%$,

- obchodná akadémia (OA): $116-12 \%$,

- iná stredná škola (I): $8-1 \%$.

Počet respondentov ako aj zastúpenie typov stredných škôl za jednotlivé roky uvádzame $\mathrm{v}$ tabul'ke č. 1 a na grafoch č. 1 a č. 2 .

Tabul'ka č. 1 Početné a percentuálne zastúpenie absolventov podl'a typu strednej školy

\begin{tabular}{|c|c|c|c|c|c|c|c|}
\hline Rok & CP & G & \% & OA & \% & I & \% \\
\hline $\mathbf{2 0 0 3}$ & $\mathbf{1 4 7}$ & 113 & 77 & 32 & 22 & 2 & 1 \\
\hline $\mathbf{2 0 0 4}$ & $\mathbf{1 7 1}$ & 144 & 84 & 25 & 15 & 2 & 1 \\
\hline $\mathbf{2 0 0 5}$ & $\mathbf{1 5 8}$ & 140 & 89 & 17 & 10 & 1 & 1 \\
\hline $\mathbf{2 0 0 9}$ & $\mathbf{1 7 7}$ & 166 & 94 & 11 & 6 & 0 & 0 \\
\hline $\mathbf{2 0 1 0}$ & $\mathbf{1 6 5}$ & 140 & 85 & 22 & 13 & 3 & 2 \\
\hline $\mathbf{2 0 1 1}$ & $\mathbf{1 5 8}$ & 149 & 94 & 9 & 6 & 0 & 0 \\
\hline
\end{tabular}

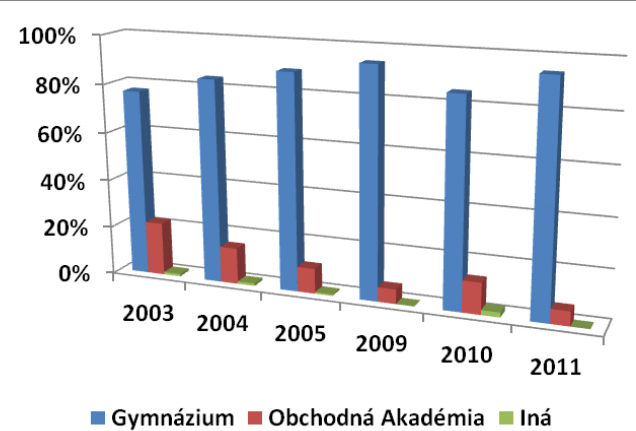

Graf č. 1Percentuálne zastúpenie absolventov podl'a typu strednej školy za jednotlivé roky

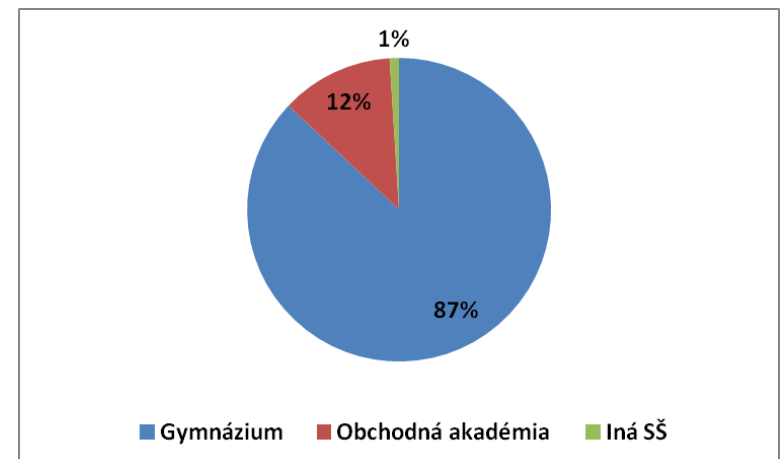

Graf č. 2 Celkové percentuálne zastúpenie absolventov podl'a typu strednej školy vo vzorke

Pri zostavovaní dotazníkových položiek na zistenie reálneho stavu $\mathrm{v}$ oblasti počítačovej gramotnosti sme vychádzali predovšetkým z platných štandardov medzinárodného konceptu European Computer Driving Licence (ECDL), úplného znenia Sylabu ECDL verzie 5.0 [5]. Zamerali sme sa na oblasti:

1. Základy IKT.

2. Práca s počítačom a správa súborov.

3. Spracovanie textu.

4. Tabul'kový kalkulátor.

5. Používanie databáz.

6. Prezentácia.

7. Prezeranie web stránok a komunikácia.

Jednotlivé oblasti a časti $\mathrm{k}$ nim patriace sme skúmali pomocou uzavretých položiek: „Na hodinách Informatiky ste sa oboznámili $s$ (pracovali s):... “- s možnost'ou vol'by odpovede áno/nie v nasledujúcich oblastiach:

- Základné pojmy (ZP) informatiky (informácia, údaj, história informatiky, ...).

- Hardvér (H) (počítač, jeho súčasti, architektúra, ...).

- Počítačové siete (PS) (LAN, MAN, WAN, GAN, topológie, ...).

V polootvorenej položke zameranej na prácu s operačným systémom (OS) študenti mali uviest' s akým konkrétnym OS sa oboznámili:

$$
\begin{array}{ll}
\circ & \text { MS Windows } \\
\circ & \text { Linux } \\
\circ & \text { Iné, uved'te .... } \\
\circ & \text { Žiadny }
\end{array}
$$

V tabul'ke č. 2 uvádzame percentuálne zastúpenie odpovedí respondentov, ktorí sa na strednej škole oboznámili/pracovali v uvedených oblastiach za jednotlivé roky.

Tabul'ka č. 2 Percentuálne zastúpenie respondentov oboznámených s prácou v oblastiach ZP. H, OS, PS

\begin{tabular}{|c|c|c|c|c|}
\hline Rok & ZP & H & OS & PS \\
\hline $\mathbf{2 0 0 3}$ & 80 & 78 & 95 & 12 \\
\hline $\mathbf{2 0 0 4}$ & 74 & 68 & 94 & 16 \\
\hline $\mathbf{2 0 0 5}$ & 77 & 82 & 97 & 27 \\
\hline $\mathbf{2 0 0 9}$ & 81 & 70 & 99 & 18 \\
\hline $\mathbf{2 0 1 0}$ & 84 & 70 & 98 & 25 \\
\hline $\mathbf{2 0 1 1}$ & 84 & 72 & 94 & 23 \\
\hline
\end{tabular}

Posuny a vývoj v uvedených oblastiach prezentuje graf č. 3. Zaznamenali sme, že v oblasti oboznámenia študentov so základnými pojmami sa situácia mení len minimálne, napriek tomu že táto téma je súčast'ou povinného obsahu výučby informatiky na SS̆. Prekvapením je, že s hardvérom, samozrejme na tej najzákladnejšej úrovni, je s postupom času oboznámených stále menej študentov. Očakávané sú výsledky 
v oblasti oboznámenia a práce $\mathrm{s}$ operačným systémom, pričom stále viac dominuje MS Windows. Očakávali sme že nízke zastúpenie študentov, ktorí sa na strednej škole oboznámili so základnými poznatkami o počítačových siet'ach bude s postupom času rást', vzhl'adom na významný nárast penetrácie Internetu, ale ako vyplýva z výsledkov, nie je tomu tak.

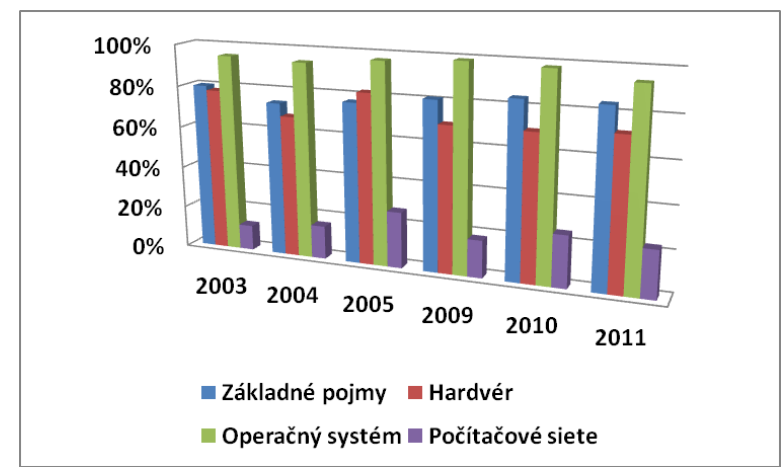

Graf č. 3 Percentuálne zastúpenie

respondentov oboznámených s oblastami $Z P, H$, OS a PS za jednotlivé roky

Ďalšie oblasti počítačovej gramotnosti sme skúmali pomocou položiek: „Na hodinách Informatiky ste sa oboznámili s (pracovali s)... “ (s možnost'ou vol'by odpovede o aký typ aplikácie išlo):

- Textové editory (TE) (MS Word, T602, TEX, iný ......., žiadny).

- Tabul'kový kalkulátor (TK) (MS Excel, Calc, iný ........, žiadny ).

- Prezentačný softvér (PS) (MS PowerPoint, iný ...., žiadny).

- Databázový softvér (D) (MS Access, Foxpro, Dbase, iný ...., žiadny).

V tabul'ke č. 3 uvádzame percentuálne zastúpenie študentov, ktorí s aplikáciami $\mathrm{v}$ príslušných oblastiach pracovali.

Tabul'ka č. 3 Percentuálne zastúpenie študentov, oboznámených s prácou $v$ oblastiach TE, TK, PS a D za jednotlivé roky

\begin{tabular}{|c|c|c|c|c|}
\hline Rok & TE & TK & PS & D \\
\hline $\mathbf{2 0 0 3}$ & 97 & 81 & 60 & 34 \\
\hline $\mathbf{2 0 0 4}$ & 97 & 81 & 49 & 60 \\
\hline $\mathbf{2 0 0 5}$ & 96 & 87 & 61 & 32 \\
\hline $\mathbf{2 0 0 9}$ & 99 & 91 & 85 & 17 \\
\hline $\mathbf{2 0 1 0}$ & 99 & 96 & 90 & 22 \\
\hline $\mathbf{2 0 1 1}$ & 98 & 91 & 93 & 19 \\
\hline
\end{tabular}

Graf č. 4 ilustruje vysoké percentuálne zastúpenie študentov, ktorí na strednej škole pracovali s textovým editorom a nárast $\mathrm{v}$ oblasti práce s tabul'kovým kalkulátorom/procesorom. Významne narástol podiel študentov, ktorí už na SŚ pracovali prezentačným softvérom. Ako môžeme vidiet' $z$ grafu č. 4 počet študentov, ktorí mali možnost' oboznámit' sa so základmi práce v oblasti databáz je klesajúci. Vo všetkých uvedených oblastiach prevažuje použitie Microsoft aplikácii.

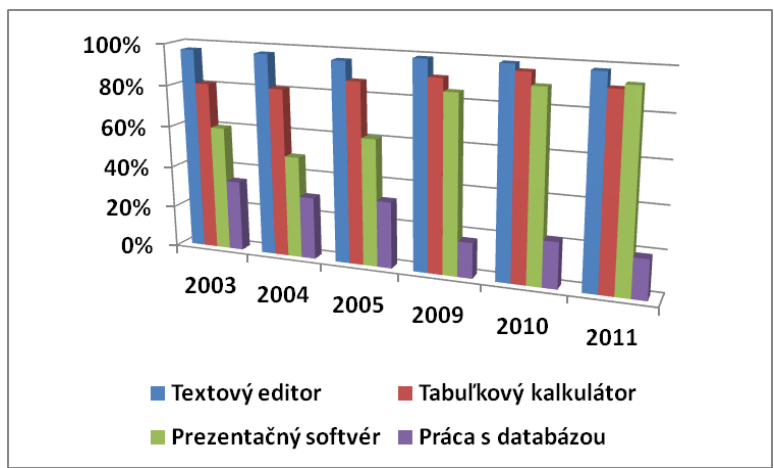

Graf č. 4 Percentuálne zastúpenie študentov oboznámených s prácou v oblastiach TE, TK, PS a $D$ za jednotlivé roky

K počítačovej gramotnosti patrí aj schopnost' komunikovat' v počítačovej sieti, využívat' služby internetu, k čomu patrí aj pochopenie základných pravidiel. Tabul'ka č. 4 uvádza percentuálne zastúpenie študentov, ktorí na SŠ využívali služby internetu (SI) (prevažne email, www, ICQ, prípadne d'alšie) Ako možno vidiet' v tabul'ke č. 4 a na grafe č. 5 s aplikáciou na prezeranie webových stránok (PWS) sa v posledných troch rokoch oboznámili takmer všetci študenti, čo je oproti predchádzajúcemu obdobiu nárast o takmer $10 \%$. Naproti tomu počet študentov ktorí sa oboznámili s internetovými protokolmi (IP), dns adresáciou, atd'. stagnuje, napriek takmer $100 \%$ zastúpeniu tých, ktorí v sieti Internet komunikujú. Teoretické poznatky o spájaní počítačov do sietí uviedli študenti len v približne $20 \%$ (graf č. 3).

Tabul'ka č. 4 Percentuálne zastúpenie študentov, oboznámených s prácou v oblastiach SI, PWS a IP za jednotlivé roky

\begin{tabular}{|c|c|c|c|}
\hline Rok & SI & PWS & IP \\
\hline $\mathbf{2 0 0 3}$ & 85 & 85 & 52 \\
\hline $\mathbf{2 0 0 4}$ & 93 & 90 & 64 \\
\hline $\mathbf{2 0 0 5}$ & 97 & 91 & 49 \\
\hline $\mathbf{2 0 0 9}$ & 100 & 100 & 62 \\
\hline $\mathbf{2 0 1 0}$ & 99 & 100 & 56 \\
\hline $\mathbf{2 0 1 1}$ & 98 & 98 & 48 \\
\hline
\end{tabular}




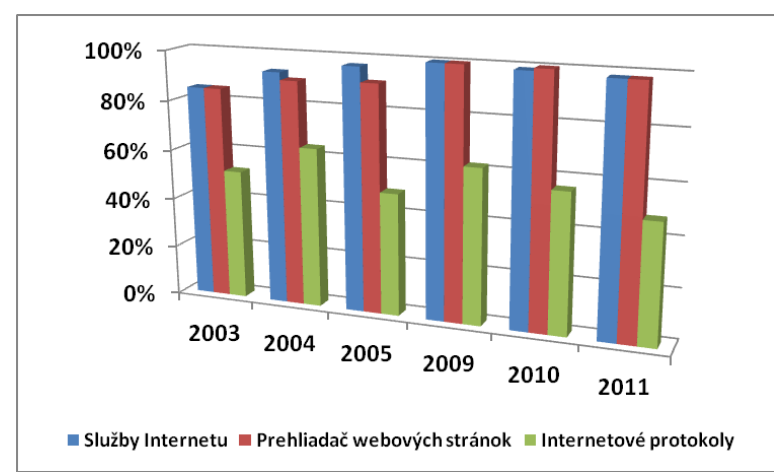

Graf č. 5 Percentuálne zastúpenie študentov oboznámených s prácou $v$ sieti Internet

\section{Oblast' informačnej gramotnosti absolventov stredných škôl}

Ako sme už uviedli, informačná gramotnost', širši pojem oproti gramotnosti počítačovej. Spočíva predovšetkým v schopnosti efektívne vyhl'adávat' a kriticky hodnotit' informácie vzt'ahujúce sa $\mathrm{k}$ určitej potrebe $\mathrm{v}$ rôznych zdrojoch a informačných systémoch. Predstavuje taktiež schopnost' využívat' moderné informačné technológie a prostriedky v bežnom živote. Pýtali sme sa preto študentov či sa stretli s pojmami: informačný systém (IS), typy informačných systémov (T), životný cyklus informačného systému, modelovanie (M) v oblasti informatiky. V tabul'ke č. 5 a na grafe č. 6 prezentujeme výsledky vyhodnotenia odpovedí študentov percentuálne zastúpenie študentov, ktorí uviedli, že sa s uvedenými pojmami/oblast’ami na strednej škole oboznámili a pracovali s nimi.

Tabul'ka č.5 Percentuálne zastúpenie študentov, oboznámených s oblastami/s prácou v oblastiach IS, T, ZC a M za jednotlivé roky

\begin{tabular}{|c|c|c|c|c|}
\hline Rok & IS & T & ZC & M \\
\hline $\mathbf{2 0 0 3}$ & 19 & 7 & 1 & 6 \\
\hline $\mathbf{2 0 0 4}$ & 16 & 9 & 6 & 0 \\
\hline $\mathbf{2 0 0 5}$ & 16 & 7 & 6 & 0 \\
\hline $\mathbf{2 0 0 9}$ & 14 & 7 & 1 & 0 \\
\hline $\mathbf{2 0 1 0}$ & 22 & 11 & 6 & 6 \\
\hline $\mathbf{2 0 1 1}$ & 28 & 21 & 1 & 1 \\
\hline
\end{tabular}

Ako možno vidiet' na grafe č. 6 zaznamenávame len mierny nárast $\mathrm{v}$ oblasti oboznámenia študentov s pojmom informačný systém a s typológiou IS. Predpokladali sme však, vzhl'adom na informatizáciu väčšiny oblastí bežného života, že študenti oboznámení s týmito pojmami budú mat' omnoho vyššie zastúpenie.

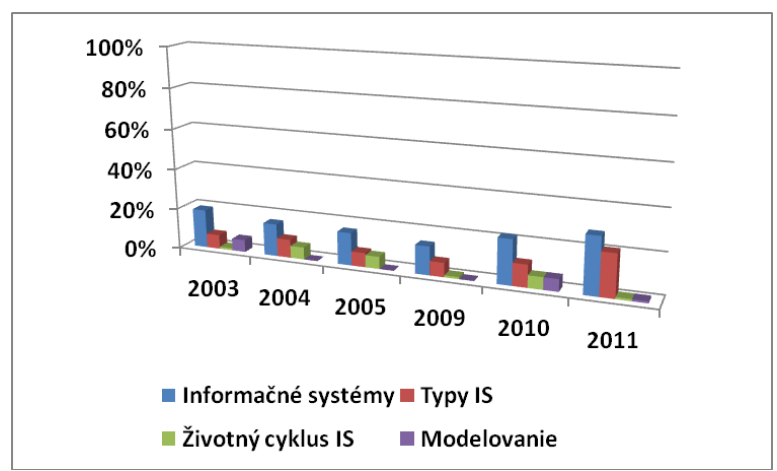

Graf č. 6 Percentuálne zastúpenie študentov oboznámených s IS, T, ZC a M za jednotlivé roky

Životný cyklus informačného systému ako aj modelovanie $\mathrm{v}$ oblasti informatiky, resp. IS sa v učebných osnovách povinného predmetu Informatika na SŠ nevyskytujú. Naše predpoklady - nízke zastúpenie kladných odpovedí na tieto otázky, sa každoročne potvrdzujú.

Oblasti výučby základov programovania oboznámenia a práce s programovacím jazykom (PJ) a algoritmizácie (A) súčast'ou obsahu povinného predmetu sú. Napriek tomu sa s programovaním na SŠ stretlo len niečo málo cez $50 \%$ študentov. Pri vyhodnotení polootvorenej položky (kde mali študenti uviest' s akým programovacím jazykom/prostredím pracovali) dominoval programovací jazyk Pascal - viac ako $90 \%$ a len vel'mi málo boli zastúpené napr. Visual Basic, C++ , Java.

V tejto oblasti nás udivuje nepomer v zastúpení tých čo sa zaoberali programovaním a tých ktorí sa stretli/oboznámili s pojmom algoritmus. Podiel študentov, ktorí uviedli prácu s programovacím jazykom bol viac ako $50 \%$, avšak v ovel'a menší bol podiel výskytu práce s algoritmami - len okolo $25 \%$. Tento trend sa rokmi nemení, resp. posúva $\mathrm{k}$ horšiemu pomeru. Uvedené skutočnosti prezentujeme v tabul'ke č. 6 a na grafe č. 7

Tabul'ka č. 6 Percentuálne zastúpenie študentov, ktorí sa na SŠ stretli/pracovali v oblasti P a A za jednotlivé roky

\begin{tabular}{|c|c|c|}
\hline Rok & PJ & A \\
\hline $\mathbf{2 0 0 3}$ & 74 & 20 \\
\hline $\mathbf{2 0 0 4}$ & 51 & 23 \\
\hline $\mathbf{2 0 0 5}$ & 51 & 33 \\
\hline $\mathbf{2 0 0 9}$ & 52 & 25 \\
\hline $\mathbf{2 0 1 0}$ & 52 & 26 \\
\hline $\mathbf{2 0 1 1}$ & 58 & 23 \\
\hline
\end{tabular}




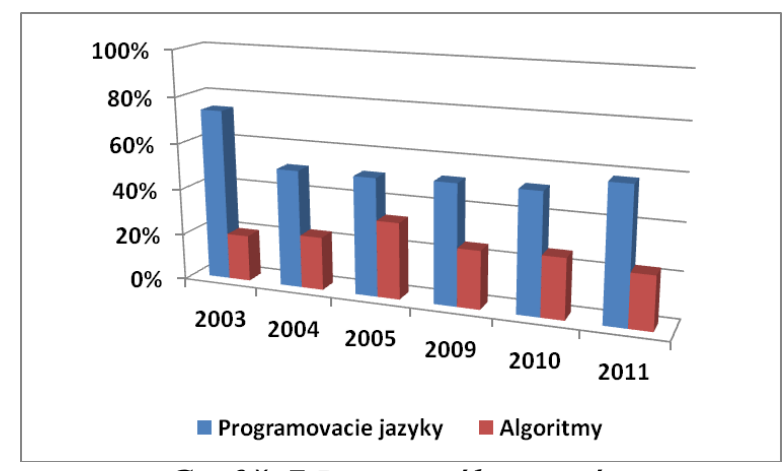

Graf č. 7 Percentuálne zastúpenie absolventov SŠ oboznámených s oblastami PJ a A za jednotlivé roky

\section{Záver}

Pracovali sme s početnou vzorkou absolventov SŠ, prevažne gymnázií. Snažili sme sa o zachovanie rovnakých podmienok pri administrácii dotazníka. $Z$ vyššie uvedených výsledkov sa preto dajú odvodit' trendy a posuny $v$ oblasti počítačovej a informačnej gramotnosti študentov.

Vo všeobecnosti môžeme konštatovat' že výučba informatiky na SŠ sa stále zameriava na obsluhu počítača a vybraných programových balíkov - počítačovú gramotnost'. Poznatkom a témam ktoré by rozvíjali informačnú gramotnost' sa venuje malá pozornost'. Predpokladáme, že aj dôsledkom vel'mi nízkej dotácie hodín.

Obsah a rozsah povinnej výučby informatiky na SŠ je podl'a nášho názoru $\mathrm{v}$ súčasnej dobe nedostatočný. Nasvedčujú tomu jednak uvedené zistenia ale aj skúsenosti $\mathrm{z}$ výučby $\mathrm{v}$ prvom ročníku na EkF TUKE.

Je potrebné brat' do úvahy radikálne pribúdajúci obsah $\mathrm{v}$ oblasti informatiky, jej široký prienik a využitie vo všetkých vedných odboroch a bežnom živote. Vyučovanie sa musí prispôsobit' rastúcim požiadavkám na informačné kompetencie a vedomostnú bázu absolventov všetkých typov škôl a potrebám pri uplatnení na trhu práce ako aj pri d’alšom štúdiu.

\section{Literatúra}

[1] BEHRENS, S. J. A conceptual analysis and historici overview of information literacy. College and Research Libraries. 1994. vol. 35, no. 4, s. 309-322.

[2] DERTOUZOS, M. 1997. What Will Be: How the New World of Information Will Change Our Lives, San Francisco: HarperCollins, HarperEdge, 1997

[3] DOSTÁL, J. Informační a počítačová gramotnost - klíčové pojmy informační výchovy. In Infotech 2007 - moderni informacni a komunikacní technologie ve vzdelávání. Olomouc: Votobia, 2007. s. 60 - 65. ISBN 97880-7220-301-7

[4] DRUCKER, P.F. 2002. To nejlepši $z$ Druckera $v$ jednom svazku, Management Press, Praha 2002, ISBN 80-7261-066-X

[5] ECDL Foundation, www.ecdl.org

[6] GÁlA, L., POUR, J., ŠEDIVÁ, Z. 2009. Podniková informatika. Praha, Grada Publishing a. s. ISBN 978-80-247-2615-1

[7] GATES, B. 1999. Byznys rychlostí myšlenky - jak uspět v digitálním věku, Management Press, Praha, ISBN 80-85943-97-2

[8] CHRÁSKA, M. Informacní technologie ve škole. In J. KROPÁC a kol. Didaktika technických predmetu. 1. vyd. Olomouc: PdF UP, s. 154. - 157. ISBN 80-244- 0848-1.

[9] Klíčové kompetence ve výuce na základní škole a gymnáziu, Národní ústav pro vzdělávání, školské poradenské zařízení a zařízení pro další vzdělávání pedagogických pracovníků (NÚV), 2011, (online) [cit. 2012-04-03] Dostupné na: http://www.vuppraha.cz/wp-content/uploads/ 2011/07/Klicove_kompetence.pdf

[10] LANDOVÁ, H. Informační gramotnost - náš problém (?). Ikaros, 2002, roč. 6, č.8 ISSN 12125075, (online) [cit. 2012-04-03]. Dostupné na: http://www.ikaros.cz/node/1024

[11] Rámcové učebné plány, (online) [cit. 201204-03] Dostupné na: http://www.statpedu.sk/sk/Statny-vzdelavaciprogram/Statny-vzdelavaci-program-pregymnaziaISCED-3a/Ramcove-ucebne-plany.alej [12] SAK, P. - SAKOVÁ, K. Počítačová gramotnost a zpusoby jejího získávání. Lupa: Server o českém internetu (online) [cit. 2012-04-14]]. Dostupné na: http://www.lupa.cz/clanky/pocitacovagramotnost-zpusoby-ziskavani/

[13] Štátny vzdelávací program pre gymnázia ISCED-3a, (online) [cit. 2012-04-03] Dostupné: http://www.statpedu.sk/files/documents/svp/gym nazia/vzdelavacie_oblasti/informatika_isced3a.pd $\mathrm{f}$

RNDr. Libuša Révészová, Ph.D.

Katedra aplikovanej matematiky

a hospodárskej informatiky,

Ekonomická fakulta,

Technická univerzita v Košiciach

Nemcovej 32, 040 01, Košice, SR

Tel: +421 0556023261

email: libusa.reveszova@tuke.sk

www pracoviska: www.ekf.tuke.sk 